J. Clin. Chem. Clin. Biochem.

Vol. 17, 1979, pp. 133-135

\title{
Selenium Content and Glutathione Peroxidase Activity in the Plasma and Erythrocytes of Non-pregnant and Pregnant Women
}

\author{
By D. Behne and W. Wolters
}

Hahn-Meitner-Institut für Kernforschung Berlin

(Received September 26/December 5, 1978)

Summary: Decreases in the glutathione peroxidase activity and in the selenium content were found in the plasma of pregnant women as compared with a control group. In the erythrocytes, both parameters remained unchanged. In both groups a fraction of about 0.90 of the glutathione peroxidase in the blood, was contained in the erythrocytes, whereas the selenium was nearly evenly distributed between plasma and red blood cells. A positive correlation existed between the total amount of selenium in the erythrocytes and that in the plasma.

\section{Selengehalt und Glutathionperoxidase-Aktivität im Plasma und in den Erythrocyten von nicht-schwangeren und schwangeren Frauen}

Zusammenfassung: Eine Abnahme der Glutathionperoxidase-Aktivität und des Selengehalts wurde im Plasma von schwangeren Frauen im Vergleich zu einer Kontrollgruppe gefunden. In den Erythrocyten blieben beide Kenngrößen unverändert. Bei beiden Gruppen war ein Anteil von 0,90 der im Blut vorhandenen Glutathionperoxidase in den Erythrocyten konzentriert, während das Selen zwischen Plasma und roten Blutkörperchen nahezu gleichverteilt vorlag. Zwischen der Selenmenge in den Erythrocyten und derjenigen im Plasma bestand eine positive Korrelation.

\section{Introduction}

Changes in the metabolism of selenium and of the selenium-containing enzyme, glutathione peroxidase (glutathione: $\mathrm{H}_{2} \mathrm{O}_{2}$ oxidoreductase, EC 1.11.1.9), were found in pregnant rats. In the serum, selenium began to decrease on the 12th day of gestation and reached its lowest level shortly before term $(1,2)$. Similarly, the GSH-peroxidase activity in the plasma of rats on the 20th day of pregnancy was found to be significantly lowered, whereas the erythrocyte enzyyme activity remained unchanged (3). In order to investigate whether similar effects occur in man, the GSH-peroxidase activity and the selenium content were measured in the plasma and erythrocytes of non-pregnant and pregnant women.

\section{Experimental}

Samples of $5 \mathrm{ml}$ of venous blood were taken from 17 apparently healthy women between 26 and 50 years of age and from 37 pregnant women between 21 and 41 years of age. Each sample was mixed with $200 \mu$ l of a 0.2 mol/1 EDTA-solution (Merck, „p. a.“) with a selenium content below the detection limit of $5 \times 10^{-9} \mathrm{~g} / \mathrm{kg}$ of EDTA-solution.

For the GSH-peroxidase assay the coupled test procedure was chosen using tert. butyl hydroperoxide as the substrate (4). In this method the decrease in NADPH concentration, which is proportional to the enzyme activity, is measured photometrically. The activity was expressed as $\mathrm{U}\left(37^{\circ} \mathrm{C}\right)=0.868 \times$ $\triangle[\mathrm{NADPH}] /[\mathrm{GSH}]_{0} \times \min (5)$ which corresponds to $\mathrm{U}\left(37^{\circ} \mathrm{C}\right)$ $=\Delta \lg [\mathrm{GSH}] / \mathrm{min}(6)$. When testing the reproducibility of the method by analysing 10 identical blood samples, a standard deviation of $10 \%$ was found. In order to determine the fraction of the non selenium-dependent and the selenium-dependent GSH-peroxidase in the erythrocytes and plasma, the enzyme activities were measured in several samples using both tert. butyl hydroperoxide and hydrogen peroxide as substrates (7).

The selenium content was determined by means of non-destructive neutron activation analysis. The analytical procedure has been described in detail elsewhere (8). It included the long-term irradiation with thermal reactor neutrons, of $25 \mathrm{mg}$ of the dried substance, sealed in highly pure silica ampoules, and the measurement of the gamma rays of $75 \mathrm{Se}$ by means of a $\mathrm{Ge}(\mathrm{Li})$ detector. In the element determination in 5 identical serum samples, the standard deviation was found to be less than $2 \%$.

As changes in the water content of the plasma or the erythrocytes during pregnancy may simulate changes in the selenium level when calculated for the wet weight or for the volume of the sample (9), the selenium content was also related to the sample dry weight. 


\section{Results and Discussion}

The mean values for the selenium content and the GSHperoxidase activity in the plasma and erythrocytes of healthy women are shown in table 1 . The distribution between the red blood cells and the plasma was calculated from these results, taking the hematocrit into consideration. It was found that, in the case of the enzyme, a fraction of $0.892 \pm 0.041$ (mean \pm standard deviation) of the amount present in the blood, was contained in the erythrocytes, whereas the selenium was nearly evenly distributed $(0.554 \pm 0.029$ in the erythrocytes).

In the determination of the enzyme activities in the erythrocytes and plasma the same results were obtained when using tert. butyl hydroperoxide or hydrogen peroxide as substrates. As the activities measured in these blood fractions therefore originated solely from the selenium-dependent GSH-peroxidase, it was possible to calculate the fraction of selenium bound to the enzyme. These values, which are listed in the last line of the table, were obtained on the assumption that the GSHperoxidase isolated from bovine blood (activity $500 \mathrm{U}$ $\left(37^{\circ} \mathrm{C}\right) / \mathrm{mg}$ enzyme (10)) is identical to the enzyme in human plasma and erythrocytes. In comparison with these values, it was found in the rat that, of the selenium present, 10 times as much was bound to the enzyme as in man (almost a fraction of 1.00 in the erythrocytes and 0.10 in the plasma (3)). In ovine ery throcytes 0.75 of the selenium was found to be contained in the GSH-peroxidase (11).

Compared to the control group, no change in the selenium content, or in the GSH-peroxidase activity was detected in the erythrocytes of pregnant women. In the plasma, however, a decrease was noted for both parameters, as can be seen in table 2 . The drop in the GSHperoxidase activity in the second trimester of pregnancy to 0.76 of that of the control group and in the third trimester to 0.68 was highly significant $(p<0.001)$. A significant drop $(p<0.001)$. in the content of sele-

Tab. 1. Selenium content and GSH-peroxidase activity in erythrocytes and plasma of healthy women $(\bar{x} \pm s ; n=17)$

\begin{tabular}{llcc}
\hline & & Plasma & \multicolumn{2}{c}{ Erythrocytes } \\
\hline Selenium & $(\mu \mathrm{g} / \mathrm{kg}$ wet weight) & $88 \pm 11$ & $140 \pm 19$ \\
& $(\mu \mathrm{g} / \mathrm{kg}$ dry weight) & $994 \pm 132$ & $473 \pm 66$ \\
& $\left(\mathrm{U}_{37} / \mathrm{kg}\right.$ wet weight) & $170 \pm 28$ & $2100 \pm 800$ \\
$\begin{array}{l}\text { GSH- } \\
\text { peroxidase }\end{array}$ & $\left(\mathrm{U}_{37} / \mathrm{kg}\right.$ hemoglobin) & --- & $7600 \pm 3100$ \\
$\begin{array}{l}\text { Se bound } \\
\text { to GSH- } \\
\text { peroxidase }\end{array}$ & $\begin{array}{l}\text { (fraction of total } \\
\text { amount) }\end{array}$ & $0.015 \pm 0.004$ & $0.11 \pm 0.05$ \\
\hline
\end{tabular}

Tab. 2. Selenium content and GSH-peroxidase activity in the plasma of pregnant women $(\bar{x} \pm s)$.

\begin{tabular}{lllll}
\hline Group & $\begin{array}{l}\text { Number } \\
\text { of } \\
\text { subjects }\end{array}$ & $\begin{array}{l}\text { Selenium GSH- } \\
(\mu \mathrm{g} / \mathrm{kg})\end{array}$ & $\begin{array}{l}\text { fraction of } \\
\text { peroxidase } \\
\left(\mathrm{U}_{37 .} / \mathrm{kg}\right)\end{array}$ & $\begin{array}{l}\text { Se, bound } \\
\text { to GSH- } \\
\text { peroxidase }\end{array}$ \\
\hline $\begin{array}{l}\text { Non- } \\
\text { pregnant }\end{array}$ & 17 & $88 \pm 11$ & $170 \pm 28$ & $0.015 \pm 0.004$ \\
$\begin{array}{l}\text { 1st } \\
\text { trimester }\end{array}$ & 2 & $89 \pm 1$ & $144 \pm 2$ & $0.012 \pm 0.001$ \\
$\begin{array}{l}\text { 2nd } \\
\text { trimester }\end{array}$ & 14 & $83 \pm 10$ & $130 \pm 29$ & $0.012 \pm 0.003$ \\
$\begin{array}{l}\text { 3rd } \\
\text { trimester }\end{array}$ & 21 & $74 \pm 12$ & $116 \pm 35$ & $0.012 \pm 0.003$ \\
\hline
\end{tabular}

nium to 0.84 of that of the control group did not occur until the third trimester.

The fact that the values for both the enzyme and the element were also significantly lowered when the content was calculated for the dry weight of the plasma sample $(p<0.001)$ proves that the changes were not caused by alterations in the protein/water ratio during pregnancy. Similar decreases in the GSH-peroxidase activity and in the selenium concentration have recently been found in the maternal plasma at the time of delivery (12).

The results show that the metabolism of the GSH-peroxidase was influenced during pregnancy and that, as the change in the enzyme level could not solely be responsible for the decrease in the plasma selenium content, other selenium compounds must have been affected too. The significance of these changes is not yet known. Further studies must be carried out to investigate whether compounds of this essential element play a role in metabolic processes during pregnancy.

It was of interest to note that both in the pregnant and in the non-pregnant group a positive correlation existed between the amount of selenium in the red blood cells and that in the plasma $(r=0.64, p<0.001)$. This might indicate that these values are somehow related. No correlation was found, however, in either group, between: the GSH-peroxidase activities in the two blood fractions; the GSH-peroxidase activity in the ery throcytes or plasma and the selenium values;

the plasma iron content and the GSH-peroxidase activity in the erythrocytes.

It would therefore appear that in the case of healthy human subjects no conclusions can be drawn from one of these parameters about any of the others.

\section{Acknowledgements}

We would like to thank Dr. H. Scholle, Klinikum Steglitz, Freie Universität Berlin, for helping us to obtain the blood samples. 


\section{References}

1. Behne, D., Elger, W., Schmelzer, W. \& Witte, M. (1976), Bioinorg. Chem. 5, 199-202.

2. Behne, D., von Berswordt-Wallrabe, R., Elger, W., Hube, G. \& Wolters, W. (1978), Experientia 34, 270-271.

3. Behne, D., von Berswordt-Wallrabe, R., Elger, W. \& Wolters, W. (1978), Experientia 34, 986-987.

4. Günzler, W. A., Kremers, H. \& Flohé, L. (1974), Z. Klin. Chem. Klin. Biochem. 12, 444-448.

5. Wendel, A., private communication.

6. Schneider, F. \& Flohé, L. (1967), Hoppe-Seyler's Z. Physiol. Chem. 348, 540-552.

7. Lawrence, R. A. \& Burk, R. F. (1976), Biochem. Biophys. Res. Commun. 71, 952-958.
8. Behne, D. \& Jürgensen, H. (1978), J. Radioanal. Chem. 42, 447-453.

9. Behne, D. \& Jürgensen, H. (1977), Lancet $I, 148$.

10. Flohé, L. \& Günzler, W. A. (1974), in "Glutathione“ (Flohé L., Benöhr, H. C., Sies, H., Waller, H. D. \& Wendel, A., eds.) p. 132-145, Georg Thieme Publishers, Stuttgart.

11. Oh, S. H., Ganther, H. E. \& Hoekstra, W. G. (1974), Biochemistry 13, 1825-1829.

12. Rudolph, N. \& Wong, S. L. (1978), Pediat. Res. 12, 789792.

Dr. Dietrich Behne

Hahn-Meitner-Institut für Kernforschung Berlin $\mathrm{GmbH}$ Glienicker Straße 100

D-1000 Berlin 39 


\section{Journal of Clinical Chemistry and Clinical Biochemistry Zeitschrift für Klinische Chemie und Klinische Biochemie}

Gemeinsames Organ der Deutschen, der Österreichischen und der Schweizerischen Gesellschaft für Klinische Chemie

We would like to draw your attention to our special

\section{Reduced Subscription Prices}

available to personal members of national societies of Clinical Chemistry associated with the IFCC (corporative members, such as hospitals, institutes, firms, etc. are strictly excluded from this offer).

Price for members of national Societies of Clinical Chemistry associated with the IFCC

DM 234, -* (for 12 issues)

(regular price DM 360,-)

Price for members of the German, the Austrian and the Swiss Society of Clinical Chemistry

DM 90,- (for 12 issues)

These orders must be sent directly to the publishers.

Upon receipt of the certificate of membership, which can be obtained from the society's treasurer, the publisher will gladly include the member's name on the subscribers' list.

* Price effective from March 1st, 1979
Wir möchten Sie auf die

\section{Vorzugspreise im Jahresabonnement} für persönliche Mitglieder der nationalen Gesellschaften für Klinische Chemie, die der IFCC angeschlossen sind, aufmerksam machen (korporative Mitglieder, wie z. B. Kliniken, Institute, Firmen usw., sind ausdrücklich hiervon ausgeschlossen).

Preis für Mitglieder der nationalen Gesellschaften für Klinische Chemie, die der IFCC angeschlossen sind

DM 234, ${ }^{\star}$ (12 Hefte)

(regulärer Preis DM 360,-)

Preis für Mitglieder der Deutschen, der Österreichischen und der Schweizerischen Gesellschaft für Klinische Chemie

$$
\text { DM 90,- (12 Hefte) }
$$

Die Bestellungen sind direkt an den Verlag zu richten.

Die für diesen verbilligten Bezug erforderiiche Bescheinigung über die Mitgliedschaft erhalten die Mitglieder vom Schatzmeister der jeweiligen Gesellschaft.

* Preis ab 1. März 1979 